\title{
FIELD INVESTIGATION AT THE FAULTLESS SITE CENTRAL NEVADA TEST AREA
}

$\mathrm{DOE} / \mathrm{NV} / 10845--\mathrm{T} 3$

DE93 005915

\author{
by
}

\author{
Jenny B. Chapman, Todd M. Mihevc and Brad Lyles \\ Water Resources Center \\ Desert Research Institute
}

\begin{abstract}
DISCLAIMER
This report was prepared as an account of work sponsored by an agency of the United States Government. Neither the United States Government nor any agency thereof, nor any of their Government. Neither the United States Government nor any agency theres liability or responsibility for the accuracy, completeness, or usefulness of any information, apparatus, product, or process disclosed, or represents that its use would not infringe privately owned rights. Reference herein to any specific commercial product, process, or service by trade name, trademark, manufacturer, or otherwise does not necessarily constitute or imply its endorsement, recommendation, or favoring by the United States Government or any agency thereof. The views and opinions of authors expressed herein do not necessarily state or reflect those of the United States Government or any agency thereof.
\end{abstract}

\section{November 1992}

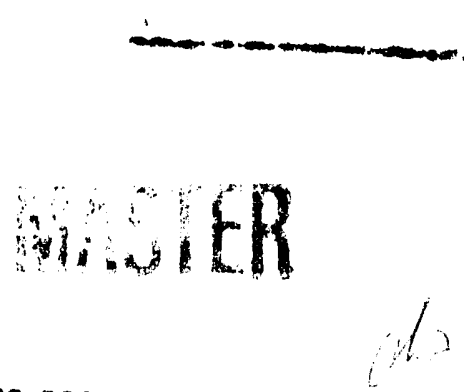




\section{Field Investigation at the Faultless Site Central Nevada Test Area}

An evaluation of groundwater monitoring at non--Nevada Test Site underground nuclear test sites (Chapman and Hokett. 1991) raised questions about the potential for radionuclide migration from the Faultless event and how to best monitor for such migration. With its long standing interest in the Faultess area and background in Nevada hydrogeology, the Desert Research Institute conducted a field investigation in FY92 to address the following issues:

- the status of chimney infilling (which determines the potential for migration)

- the best level(s) from which to collect samples from the nearby monitoring wells. HTH-1 and HTH-2 (Figure 1)

- the status of hydraulic heads in the monitoring well area following records of sustained elevated post-shot heads.

The field investigation was conducted from July 27 to 31 and August 4 to 7, 1992. Temperature and electrical conductivity logging were pertormed in $\mathrm{HTH}-1, \mathrm{HTH}-2$, and UC-1-P-2SP. Water samples were collected from HTH-1 and HTH-2. Lawrence Livermore National Laboratory (LLNL) also collected samples during the July trip, including samples from UC-1-P-2SR.

This report presents the data gathered during these field excursions and some preliminary conclusions. Full interpretation of the data in light of the issues listed above is planned for FY93.

\section{HTH-1}

The depth to water at HTH-1 was measured as $532.2 \mathrm{ft}$ below land surface (bls) on July $28,1992$. This is at an elevation of $5478.8 \mathrm{ft}$ referenced to mean sea level (msl) and is almost 20 feet higher than the pre-event water level elevation of $5459 \mathrm{ft} \mathrm{msl}$. Though the well is cased to $3704 \mathrm{ft}$ (Figure 2 ), an obstruction was encountered at $2818 \mathrm{ft}$ that prevented deeper penetration. No record of this obstruction could be found, though records of previous water sampling indicate that it may have occurred as a result of the Faultless event. Water samples were collected from HTH-1 in 1967, prior to the Faultless event. and included a sample from the screen at 2950 to $3010 \mathrm{ft}$. The next recorded sampling, in 1969 (a year after the shot), only included a sample collected at $2887 \mathrm{ft}$ (Thordarson, 1985). It is likely that this sample was collected at the maximum depth at that time. The reason for the apparent additional loss of hole from 2887 in 1969 to 2818 in 1992 is unknown, but could be the collection of loose fill.

Logging was performed on August 5, 1992. Measured downhole temperatures ranged from 17.6 to $44.0^{\circ} \mathrm{C}$ (Figure 2). Electrical conductivity varied from 507 to $599 \mu \mathrm{mhos} / \mathrm{cm}$ at $25^{\circ} \mathrm{C}$ (Figure 2). Samples were collected on July 28 and 29 from the middle of the eight accessible screened horizons. Samples could not be collected at the screens located 2950-3010 and 3590-3665 ft bls because the obstruction at $2818 \mathrm{ft}$ prevented lowering the bailer to those depths. Field parameters measured when the samples were drained from the discrete sampler are given in Table 1 . The lower temperatures of the deeper samples as compared to the downhole measurements (e.g., for the sample from $2675 \mathrm{ft}: 26.5^{\circ} \mathrm{C}$ measured from the bailer as compared to a logged value of $41.5^{\circ} \mathrm{C}$ ) are attributed to cooling as the bailer was pulled through the water column.

Electrical conductivity measurements at the surface and downhole were comparable, varying beiween 508 and $542 \mu \mathrm{mhos} / \mathrm{cm}$ at $25^{\circ} \mathrm{C}$. pH varied from 8.15 at the bottom screen to 8.44 at 2250 ft. Alkalinity, determined by field titration with sulfuric acid, ranged from $189 \mathrm{mg} / \mathrm{L}$ as $\mathrm{HCO}_{3}$ at $775 \mathrm{ft}$ to $226 \mathrm{mg} / \mathrm{L}$ at $2250 \mathrm{ft}$. 
The chemical analyses for the eight samples are contained in the Appendix.

\section{HTH-2}

The depth to water at HTH-2 was measured as $553.2 \mathrm{ft}$ bls on July 29, 1992. This water level is at an elevation of $5472 \mathrm{ft} \mathrm{msl}$, and is almost 12 feet higher than the pre-event water level in this hole $15.460 \mathrm{ft}$ msi). The bottom of the hole was tagged at $987 \mathrm{ft}$. slightly more shallow than the $1001 \mathrm{ft}$ (I) casing recorded as being in the hole (Figure 3 ). Judging by the appearance of the bottom sample (brown and cloudy), it is likely that loose formation materials have filled in the bottom $14 \mathrm{ft}$ of the casing.

Logging was performed on August 0, 1992. Measured downhole temperatures ranged from 17.9 to $20.7^{\circ} \mathrm{C}$ (Figure 3). Electrical conductivity was lower in $\mathrm{HTH}-2$ than in $\mathrm{HTH}-1$, ranging from 234 to $393 \mu \mathrm{mhos} / \mathrm{cm}$ at $25^{\circ} \mathrm{C}$ (Figure 3). Two samples were collected in July 29,1992 at 750 and $975 \mathrm{ft}$ bls. HTH-2 has slotted casing throughout its saturated interval: the sampling horizons were chosen to match the perforated horizons in $\mathrm{H}$ TH -1 . Field parameters measured when the water was drained from the discrete sampler are given in Table 2. Logging and surface temperatures are comparable for the sample intervals. though downhole conductivity measurements are higher ( approximately $300 \mu \mathrm{mhos} / \mathrm{cm}$ at $25^{\circ} \mathrm{C}$ for both samples at the surface, compared to 364 and 381 downhole). The lower values are supported by the laboratory measurements, given in the Appendix. Alkalinity was also lower in HTH-2 as compared to HTH-1, with measurements of 161 and $177 \mathrm{mg} / \mathrm{L}$ as $\mathrm{HCO}_{3}$.

An additional sample was collected on August 6 at a depth of $650 \mathrm{ft}$ because the logging identified. a lower salinity zone from the water table to a depth of about $675 \mathrm{ft}$. This analysis is also in the appendix, though no field parameters were recorded.

\section{UC-1-P-2SR}

The depth to water at UC-1-P-2SR was measured as $750.6 \mathrm{ft}$ bls (elevation of $5333.9 \mathrm{ft} \mathrm{msl}$ ) on August 6,1992 . An obstruction was encountered at $2614.8 \mathrm{ft}$ bls, slightly higher than the obstruction at 2631.9 reported by Thordarson $(1985)$. Measured downhole temperatures ranged from $18.4^{\circ} \mathrm{C}$ near the water table to $52.8^{\circ} \mathrm{C}$ at the bottom of the hole (Figure 4 ). The increase in temperature primarily occurs in the bottom $300 \mathrm{ft}$ of the hole. Electrical conductivity ranges from 277 to 740 umhos/cm at $25^{\circ} \mathrm{C}$ (Figure 4) with two depths where sharp increases occur: a jump from approximately 280 to $375 \mu \mathrm{mhos} / \mathrm{cm}$ at $25^{\circ} \mathrm{C}$ between 975 and $1000 \mathrm{ft}$ bls, and a rise from 450 to $675 \mu \mathrm{mhos} /$ $\mathrm{cm}$ at $25^{\circ} \mathrm{C}$ at $2150 \mathrm{ft}$ bls. DRI did not collect samples from this hole because of the expected radionuclide concentrations; samples were collected by LLNL on July 28 and 29 .

\section{Preliminary Interpretations}

The uniformity in $\mathrm{pH}$ and EC throughout the water column in HTH-1 and the steady increase in temperature with depth suggest a well-mixed water column rather than discrete horizons at each screen. The water level measurement indicates that head in the hole is still elevated from pre-shot water table measurements, and the chemistry results suggest that the reason for this may be the contribution of water from a deeper, higher pressure horizon, to the overlying units. The candidate for this is the densely welded tuff horizon across from the screen at 2400 to $2460 \mathrm{ft}$ bls.

The contrast between the chemistry in the shallow part of HTH-1 and in HTH-2 is distinct and indicates that $\mathrm{HTH}-1$ is no longer representative of natural conditions in the upper aquifers. Comparing the field parameters from HTH-2 with shallow samples from $\mathrm{HTH}-1$ collected during or shortly after drilling (Dinwiddie and Shroder, 1971) suggests that the shallow horizon penetrated by the two 
wells was chemically similar at the me of drilling. The higher salinity, warmer, water moving upward from the welded tuti penetrated $\because \mathrm{HTH}-1$ has not migrated laterally through the shallow zone from HTH-1 to HTH-2 (approximate. " $)($ ) ft). Thus, the two wells currently sample different water masses. Within HTH-2 itself, there a ductivity logs, with the lowest salinity water above 70() $\mathrm{ft}$ bls. This distinction is not seen in the water samples, but may be a function of sampling too deep to capture the shallower zone (the uppermost sample was collected at $650 \mathrm{ft}$ blsi. Though $\mathrm{HTH}-1$ and $\mathrm{HTH}-2$ are sampling different zones of water quality, the head levels in both of these zones have been elevated since the Faultess event, though to differing degrees. Before the shot. the water table elevation in both holes was approximately $5460 \mathrm{ft}$ msl. Now, the water level in HTH-1 is almost $5479 \mathrm{ft}$ and in HTH-2 is almost 5472 it. There are three possible causes for the increased water levels: pressure buildup from the explosion (a transient effect), seismic compression (gravitational collapse) causing a permeability decrease, or a localized pressure mound caused by the intersection of the higher pressure zone in the welded tuff intersected in $\mathrm{HTH}-1$.

The water level in UC-1-P-2SR is almost $200 \mathrm{ft}$ below the estimated pre-event elevation of 5532.5 ft msi (Thordarson, 1987). The temperature log for the post-shot hole. UC-1-P-2SR, is essentially identical to that in HTH-2 in the upper $1000 \mathrm{ft}$ bls, with both of these being markedly cooler than the water in HTH-1. This suggests that water is infilling the cavity from above or laterally, and is relatively unaffected by cavity conditions below. The remperature and electrical conductivity logs show three distinct zones in UC-1-P-2SR: an upper zone of conductivity below $300 \mu \mathrm{mhos} / \mathrm{cm}$ at $25^{\circ} \mathrm{C}$ and temperatures below $25^{\circ} \mathrm{C}$. a middle zone of very constant conductivity and water temperature (approximately $375 \mu \mathrm{mhos} / \mathrm{cm}$ at $25^{\circ} \mathrm{C}$ and a water temperature of 26 to $27^{\circ} \mathrm{C}$ ), and a lower zone defined by a very sharp increase in conductivity at $2150 \mathrm{ft}$ bls to around $675 \mu \mathrm{mnos} / \mathrm{cm}$ at $25^{\circ} \mathrm{C}$ and rapid increases in temperature with depth to the maximum at the bottom of the accessible hole, $52.8^{\circ} \mathrm{C}$. Presumably this lower zone is affected by cavity conditions. These zones appear at different levels than those identified by Thordarson (1987) and their characteristics have changed. In particular. the conductivity of the lower zone is much higher now as compared to the data from Thordarson.

\section{Future Work}

The preliminary interpretations discussed above will be examined more fully in FY 1993. Historic water level trends will be included with the present data to allow estimation of chimney filling and increasc understanding of excess pressures outside the chimney area. This will include an attempt to verify pre-shot heads, particularly in the vicinity of UC-1-P-2SR, through literature review. Simple modeling of the Faultless environment may be necessary to isolate plausible scenarios for the observed hydraulic response to the test. The chemical and isotopic data will be examined to develop a more clear detinition of the discrete water quality zones intercepted by each well, from which recommendations of sampling horizons will be made.

Additional field work may also be pertormed. In particular, a thermal flowmeter could measure the magnitude and direction of water tlow in the boreholes (measurements were attempted during this field excursion but were unsuccessful due to problems with the packer). This could reveal if water is indeed entering HTH -1 from the welded tuff, and whether this unit is contributing to ISC-1-P-2SR. 


\section{References}

Chapman. J.B. and S.L. Hokett, 1991. Evaluation of Groundwater Monitoring at Offsite Nuclear Test Areas. DOE/NV/10845-i)7, LC--7()3. Desert Research Institute Water Resources Center Publivation $\# 45085$, 82p.

Dinwiddie. G.A. and L.J. Schroder, 1971, Summary of Hydraulic Testing in and Chemical Analyses of Water Samples From Deep Exploratory Holes in Little Fish Lake, Monitor, Hot Creek, and Little Smoky Valleys, NV. U.S. Geological Survey Report USGS-474-90, 70p.

Thordarson. W., 1987. Hydrogeology of the Faultless Site. Nye County, NV. U.S. Geological Survey Open-File Repor 36-4342. 4)p.

Thordarson, W., 1985, Hydrogeologic Monitoring at the Faultless Site, Nye County, NV. U.S. Geological Survey Open-File Report $84-580,37 p$.

\section{List of Tables}

Table 1. Field parameters measured on samples from HTH-1.

Table 2. Field parameters measured on samples from $\mathrm{HTH}-2$.

\section{List of Figures}

Figure 1. Map showing the location of the Faultless site within Hot Creek Valley and detail of the wells examined in this study.

Figure 2. Completion diagram and temperature and electrical conductivity logs for well HTH-1. An obstruction was encountered at 2818 ft so that the bottom two screens could not be accessed.

Figure 3. Completion diagram and temperature and electrical conductivity logs for well HTH-2.

Figure 4. Completion diagram and temperature and electrical conductivity logs for well UC-1-P-2SR. An obstruction was encountered at $2614.8 \mathrm{ft}$. 
Table 1. Field Parameters Measured on Samples From HTH-1

\begin{tabular}{|c|c|c|c|c|c|c|}
\hline $\begin{array}{c}\text { Date } \\
(\mathbf{m}-\mathbf{d}-\mathbf{y})\end{array}$ & $\begin{array}{c}\text { Time } \\
(\mathrm{hr}: \mathrm{min})\end{array}$ & $\begin{array}{c}\text { Depth } \\
(\mathrm{ft})\end{array}$ & $\begin{array}{c}\text { Temp. } \\
\left({ }^{\circ} \mathrm{C}\right)\end{array}$ & $\begin{array}{c}\text { E.C. } \\
(\mu \mathrm{mhos} / \\
\mathrm{cm} @ 25 \mathrm{C})\end{array}$ & $\mathrm{pH}$ & $\begin{array}{c}\mathrm{HCO}_{3} \\
(\mathrm{mg} / \mathrm{L})\end{array}$ \\
\hline $7-28-92$ & $11: 00$ & 775 & 23 & 536 & 8.23 & 189 \\
\hline $7-28-92$ & $12: 20$ & 1050 & 26 & 519 & 8.35 & 217 \\
\hline $7-28-92$ & $13: 15$ & 1450 & 26 & 542 & 8.38 & 211 \\
\hline $7-28-92$ & $14: 30$ & 1690 & 26 & 516 & 8.27 & 220 \\
\hline $7-28-92$ & $15: 30$ & 1895 & 25 & 524 & 8.34 & 211 \\
\hline $7-28-92$ & $16: 45$ & 2250 & 24 & 516 & 8.44 & 226 \\
\hline $7-29-92$ & $12: 50$ & 2430 & 24.5 & 509 & 8.25 & 199 \\
\hline $7-29-92$ & $15: 00$ & 2675 & 26.5 & 508 & 8.15 & 205 \\
\hline
\end{tabular}

Table 2. Field Parameters Measured on Samples From HTH-2

\begin{tabular}{|c|c|c|c|c|c|c|}
\hline $\begin{array}{c}\text { Date } \\
(\mathbf{m}-\mathbf{d}-\mathbf{y r})\end{array}$ & $\begin{array}{c}\text { Time } \\
(\mathbf{h r}: \mathbf{m i n})\end{array}$ & $\begin{array}{c}\text { Depth } \\
(\mathbf{f t})\end{array}$ & $\begin{array}{c}\text { Temp. } \\
\left({ }^{\circ} \mathbf{C}\right)\end{array}$ & $\begin{array}{c}\text { E.C. } \\
(\mu \mathbf{m h o s} / \\
\mathbf{c m @ 2 5 C})\end{array}$ & $\mathbf{p H}$ & $\begin{array}{c}\mathrm{HCO}_{3} \\
(\mathbf{m g} / \mathbf{L})\end{array}$ \\
\hline $7-29-92$ & $18: 30$ & 750 & 19.5 & 303 & 7.84 & 177 \\
\hline $7-29-92$ & $19: 15$ & 975 & 20.5 & 299 & 7.94 & 161 \\
\hline
\end{tabular}




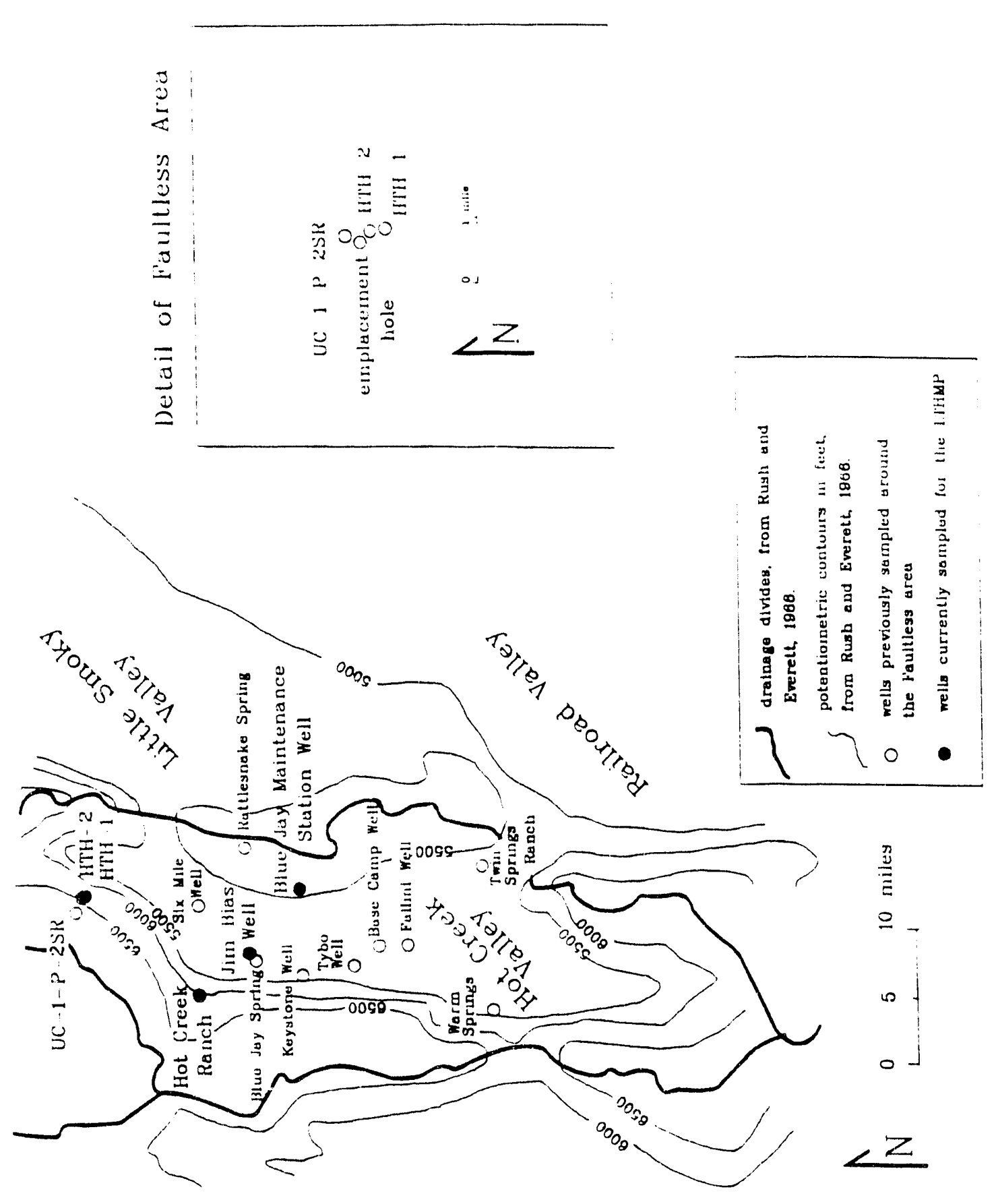



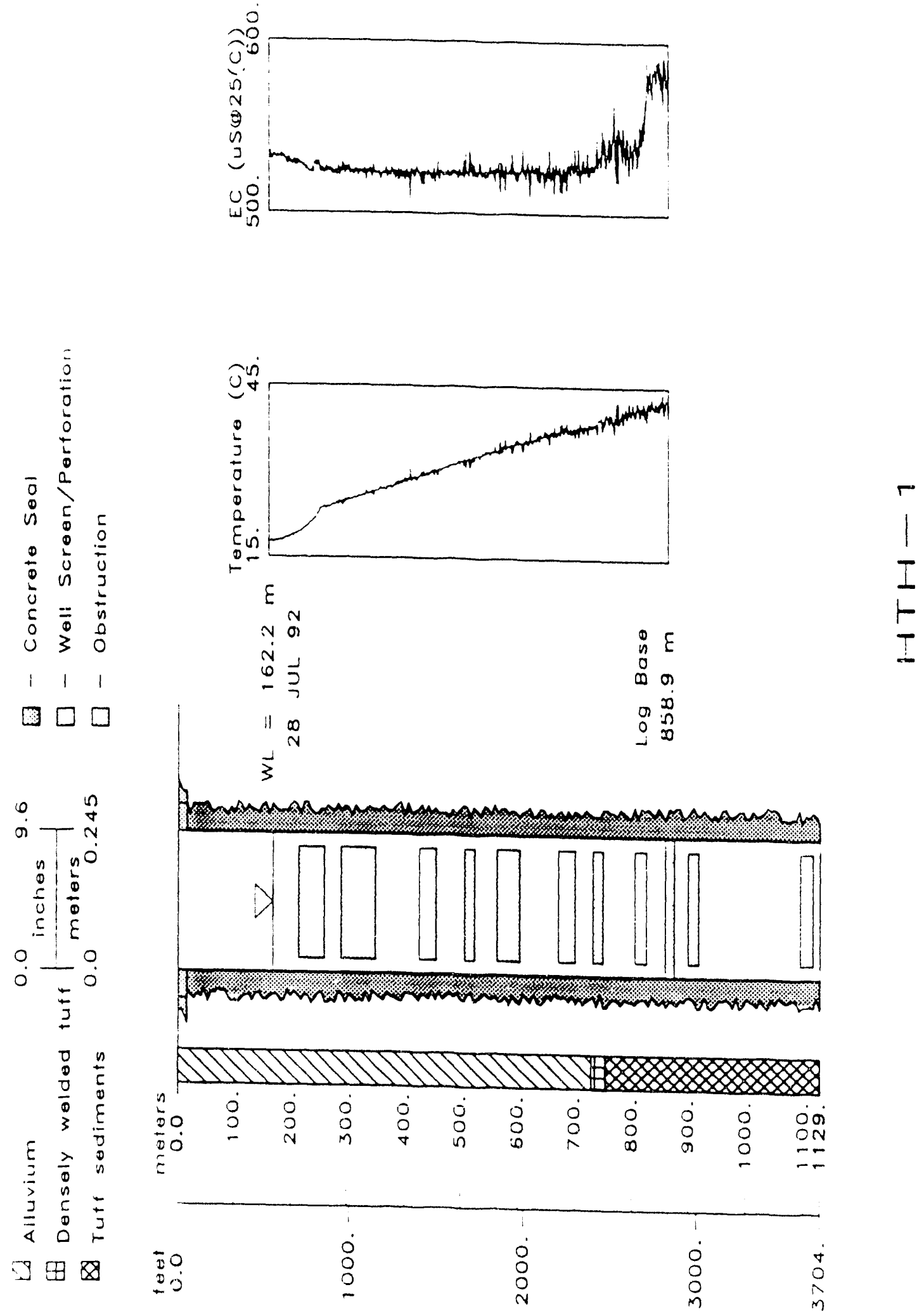

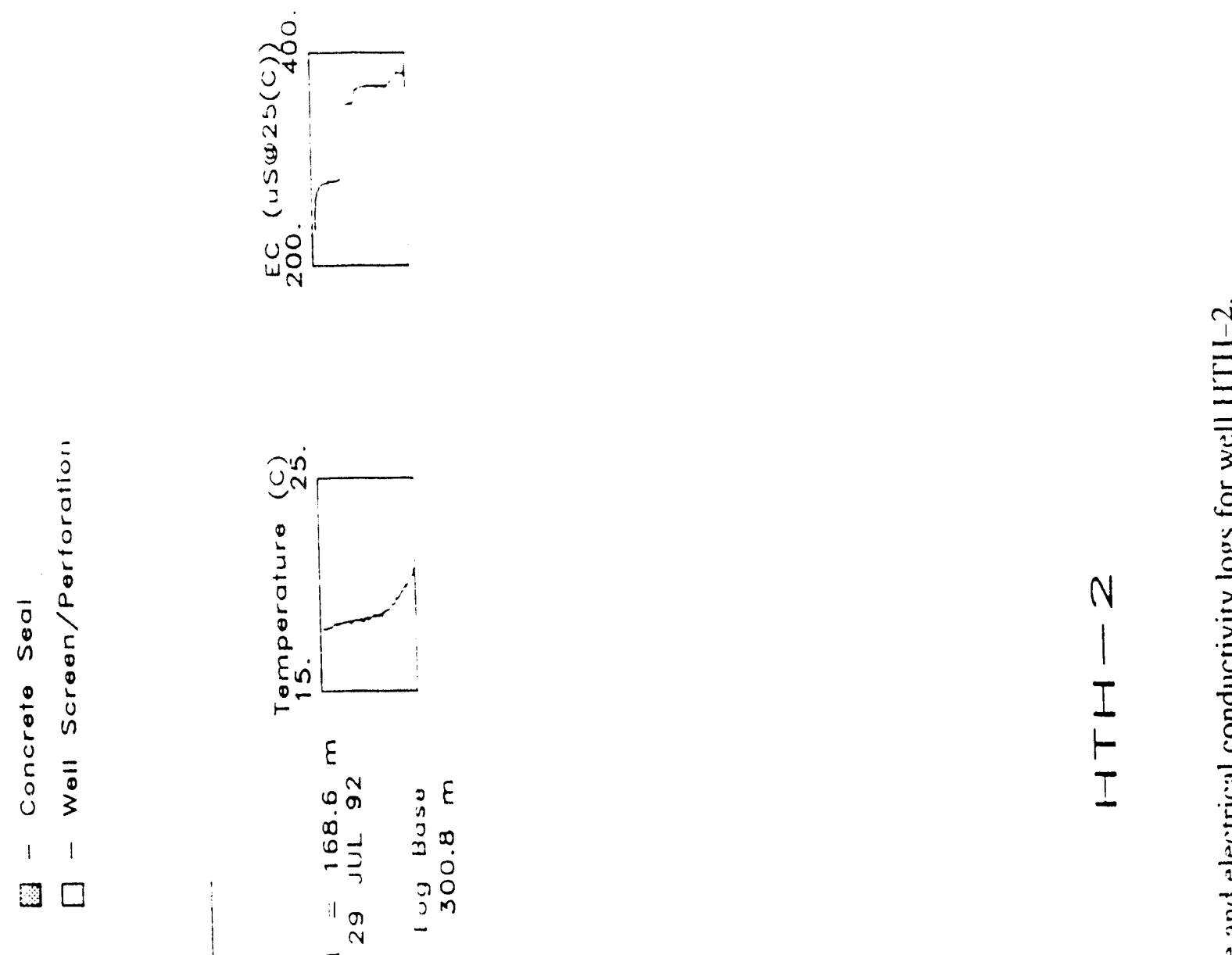

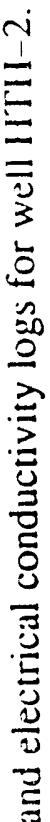
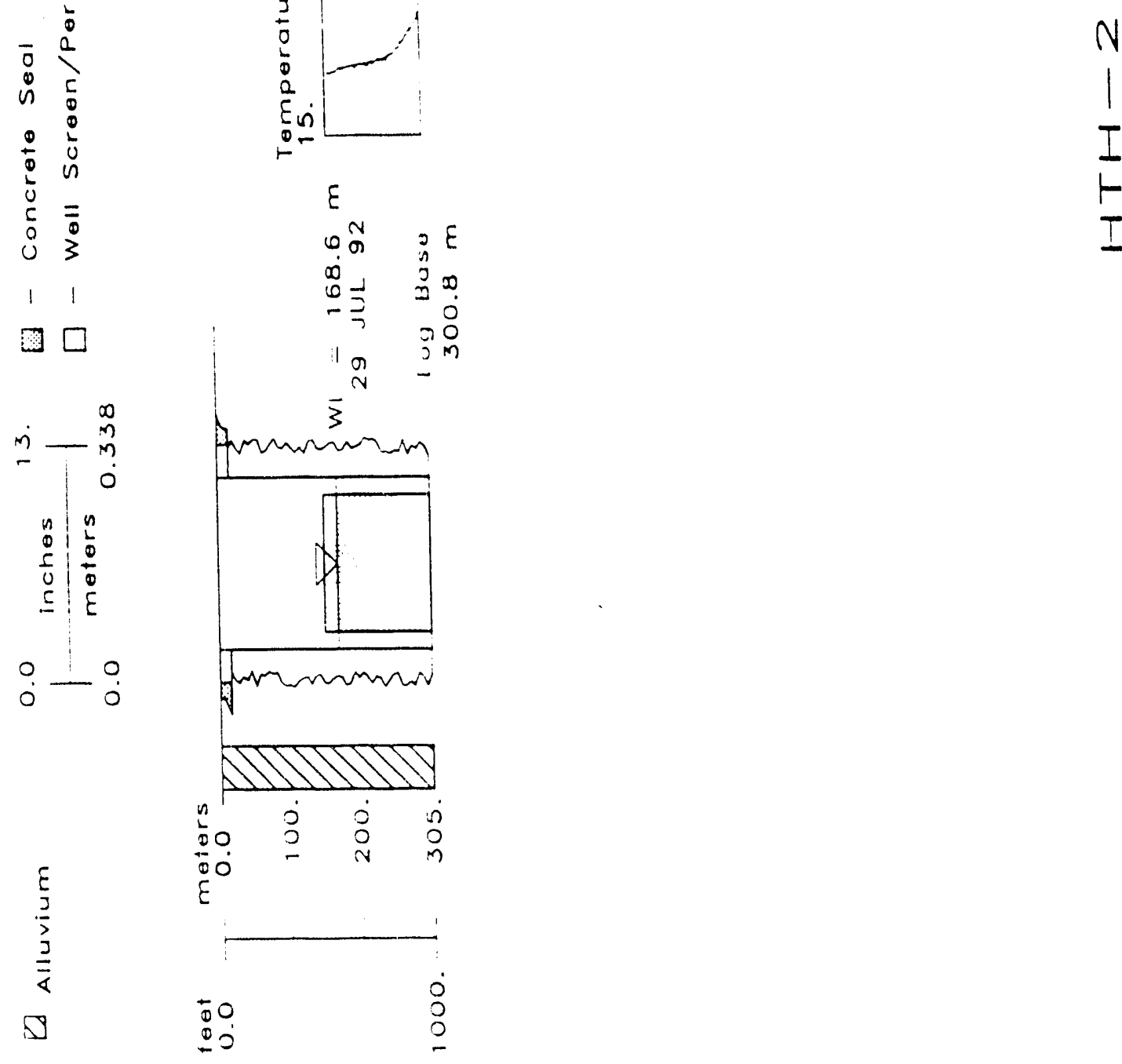

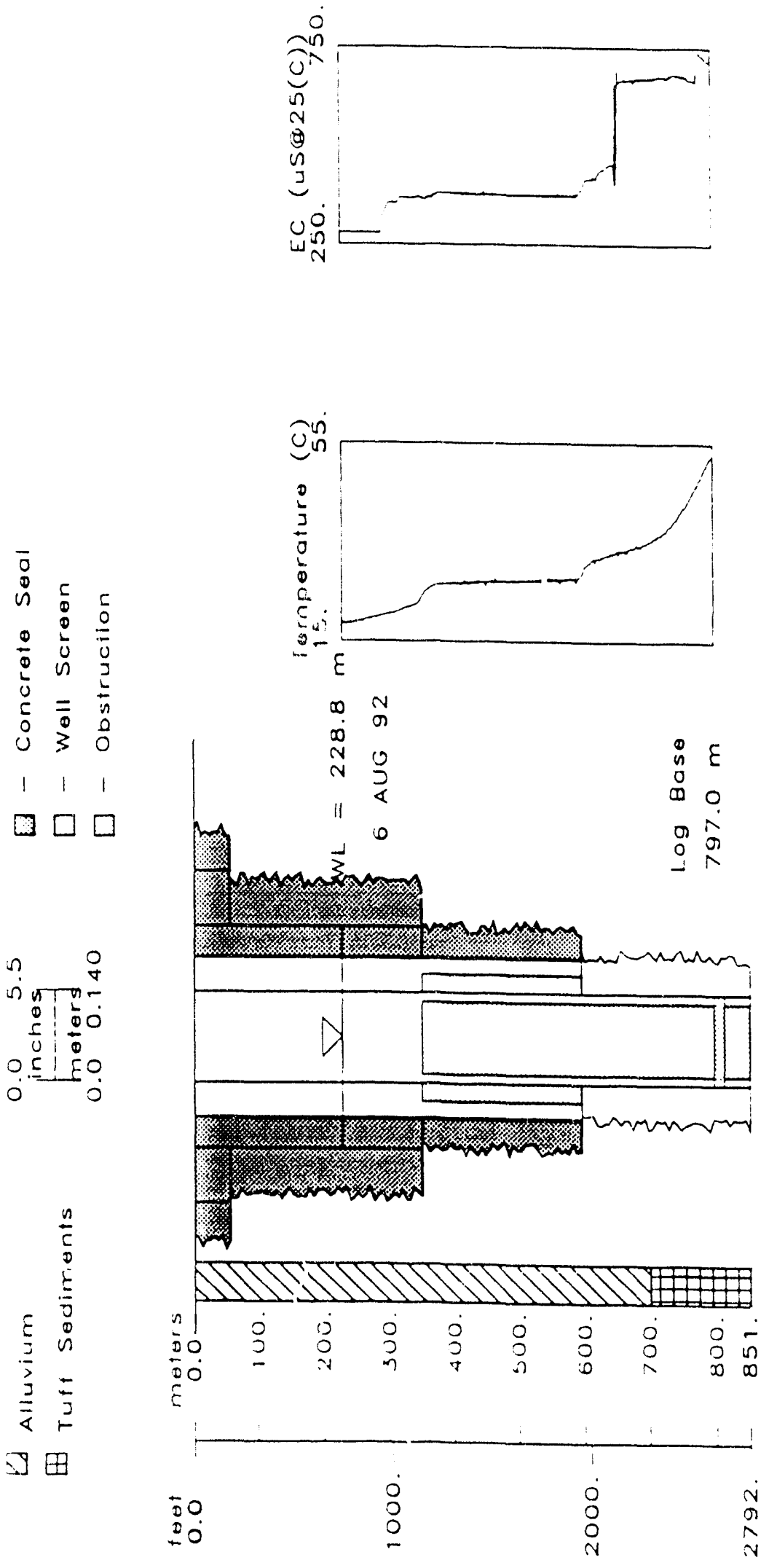
Appendix

Chemical Analyses of Faultless Water Samples 


\section{WRC Waterläb}

Requested by: Chanman. jenny Project: DOE Shoal Offsite
Date submitted: 31-Jul-92

File name: 25482DOE.dat

\begin{tabular}{|c|c|c|c|c|c|c|c|c|}
\hline Sample \#: & \multicolumn{2}{|c|}{$25+82$} & \multicolumn{2}{|c|}{25483} & \multicolumn{2}{|c|}{25484} & \multicolumn{2}{|c|}{25485} \\
\hline Sample Date: & \multicolumn{2}{|c|}{$23-J u 1-92$} & \multicolumn{2}{|c|}{$28-5 u l-92$} & \multicolumn{2}{|c|}{ 28-Jul-92 } & \multicolumn{2}{|c|}{ 28-Jul-92 } \\
\hline Sample Name: & \multicolumn{2}{|c|}{ HTH-1 775} & \multicolumn{2}{|c|}{ HT:A-1 1050} & \multicolumn{2}{|c|}{ HTH-1 1450} & \multicolumn{2}{|c|}{ HTH-1 1690} \\
\hline $\mathrm{EC}$ & \multicolumn{2}{|c|}{$5+5$} & \multicolumn{2}{|c|}{539} & \multicolumn{2}{|c|}{542} & \multicolumn{2}{|c|}{546} \\
\hline $\mathrm{SiO} 2$ & \multicolumn{2}{|c|}{55.4} & \multicolumn{2}{|c|}{56.0} & \multicolumn{2}{|c|}{56.5} & \multicolumn{2}{|c|}{57.5} \\
\hline $\mathrm{pH}$ & \multicolumn{2}{|c|}{8.40} & \multicolumn{2}{|c|}{8.31} & \multicolumn{2}{|c|}{8.30} & \multicolumn{2}{|c|}{8.43} \\
\hline & $\mathrm{mg} / \mathrm{l}$ & $\mathrm{pm}$ & $\mathrm{in} / \mathrm{g} / \mathrm{l}$ & $\mathrm{epm}$ & $\mathrm{mg} / \mathrm{l}$ & $\mathrm{epm}$ & $\mathrm{mg} / \mathrm{l}$ & epm \\
\hline $\mathrm{HCO} 3$ & 238 & 3.901 & 243 & 3.983 & 244 & 3.999 & 238 & 3.901 \\
\hline $\mathrm{CO} 3$ & +.1 & 0.137 & 0.6 & $0.02 i j$ & 0.4 & 0.013 & 4.7 & 0.157 \\
\hline $\mathrm{Cl}$ & 16.7 & 0.471 & 16.8 & $0.4,4$ & 16.8 & 0.474 & 16.8 & 0.474 \\
\hline SO4 & 33.5 & 0.697 & 33.4 & 0.695 & 33.5 & 0.697 & 33.4 & 0.695 \\
\hline NO3 & $<.04$ & & $<.04$ & & $<.04$ & & $<.04$ & \\
\hline $\mathrm{F}$ & 9.4 & 0.495 & 10.4 & 0.547 & 10.4 & 0.547 & 10.5 & 0.553 \\
\hline Total Anions & & 5.701 & & 5.719 & & 5.731 & & 5.779 \\
\hline $\mathrm{Ya}$ & 126 & 5.481 & 125 & 5.438 & 125 & 5.438 & 125 & 5.438 \\
\hline $\mathrm{k}$ & 1.52 & 0.039 & 1.39 & 0.036 & 1.37 & 0.035 & 1.37 & 0.035 \\
\hline $\mathrm{Ca}$ & 3.28 & 0. 164 & 3.10 & 0.155 & 3.53 & 0.176 & 4.51 & 0.225 \\
\hline $\mathrm{Mg}$ & 0.10 & 1).008 & 0.07 & 0.006 & 0.07 & 0.006 & 0.09 & 0.007 \\
\hline Total Cations & & 5.692 & & 5.634 & & 5.654 & & 5.705 \\
\hline Anions/Cations & & 1.002 & & 1.015 & & 1.014 & & 1.013 \\
\hline
\end{tabular}




\section{WRC Wateriab}

Requested by: Chapman. Jenny

Project: DOE Shoal Offsite
Date submitted: $31-J u l-92$

File name: 25482DOE.dat

\begin{tabular}{|c|c|c|c|c|c|c|c|c|}
\hline Sample \#: & \multicolumn{2}{|c|}{25486} & \multicolumn{2}{|c|}{25487} & \multicolumn{2}{|c|}{25488} & \multicolumn{2}{|c|}{25489} \\
\hline Sample Dale: & \multicolumn{2}{|c|}{$28-\mathrm{Jul}-92$} & \multicolumn{2}{|c|}{$28-\mathrm{Jul}-92$} & \multicolumn{2}{|c|}{$29-\mathrm{Jul}-92$} & \multicolumn{2}{|c|}{$29-\mathrm{Jul}-92$} \\
\hline Sample Name: & \multicolumn{2}{|c|}{ HTH-1 1895} & \multicolumn{2}{|c|}{ HTH-1 2250} & \multicolumn{2}{|c|}{ HTH- 12430} & \multicolumn{2}{|c|}{ HTH-1 2675} \\
\hline $\mathrm{EC}$ & \multicolumn{2}{|c|}{$\vdots 4()$} & \multicolumn{2}{|c|}{$5+3$} & \multicolumn{2}{|c|}{548} & \multicolumn{2}{|c|}{561} \\
\hline $\mathrm{SiO} 2$ & \multicolumn{2}{|c|}{56.8} & \multicolumn{2}{|c|}{57.1} & \multicolumn{2}{|c|}{64.3} & \multicolumn{2}{|c|}{66.2} \\
\hline \multirow[t]{2}{*}{$\mathrm{pH}$} & \multicolumn{2}{|c|}{8.32} & \multicolumn{2}{|c|}{8.40} & \multicolumn{2}{|c|}{8.27} & \multicolumn{2}{|c|}{8.24} \\
\hline & $\mathrm{mg} / \mathrm{l}$ & $\mathrm{ipm}$ & $\mathrm{mg} / \mathrm{l}$ & $\mathrm{epm}$ & $\mathrm{mg} / \mathrm{l}$ & epm & $\mathrm{mg} / \mathrm{l}$ & epm \\
\hline $\mathrm{HCO} 3$ & $2+2$ & 3.966 & 237 & $\therefore .884$ & 247 & 4.048 & 249 & 4.081 \\
\hline $\mathrm{CO} 3$ & 0.9 & 0.030 & 36 & 0.120 & & & & \\
\hline $\mathrm{Cl}$ & 16.8 & 0.474 & 17.9 & 0.479 & 18.2 & 0.513 & 19.1 & 0.539 \\
\hline SO4 & 33.1 & 0.689 & 33.5 & 0.697 & 33.4 & 0.695 & 34.5 & 0.718 \\
\hline$\because 23$ & $<.04$ & & $<.04$ & & $<.04$ & & $<.04$ & \\
\hline$F$ & 10.5 & 0.553 & 10.5 & 0.553 & 9.4 & 0.495 & 10.4 & 0.547 \\
\hline Total Anions & & 5.712 & & 5.734 & & 5.752 & & 5.885 \\
\hline $\mathrm{Na}$ & 127 & 5.524 & 125 & 5.438 & 128 & 5.568 & 129 & 5.611 \\
\hline K & 1.37 & 0.035 & 1.42 & 0.036 & 1.55 & 0.040 & 1.55 & 0.040 \\
\hline $\mathrm{Ca}$ & 3.22 & 0.161 & 3.06 & 0.153 & 2.95 & 0.147 & 2.93 & 0.146 \\
\hline $\mathrm{Mg}$ & 0.07 & 0.006 & 0.05 & 0.004 & 0.06 & 0.005 & 0.07 & 0.006 \\
\hline Total Cations & & 5.726 & & 5.631 & & 5.760 & & 5.803 \\
\hline Anions/Cations & & 0.998 & & 1.018 & & 0.999 & & 1.014 \\
\hline
\end{tabular}




\section{WRC Waterlab}

Requested by: Chapman. Jenny

Project: DOE Shoal Offisite
Date submitled: $31 \cdot 5$ ul-92

File name: 25482DOE.dat

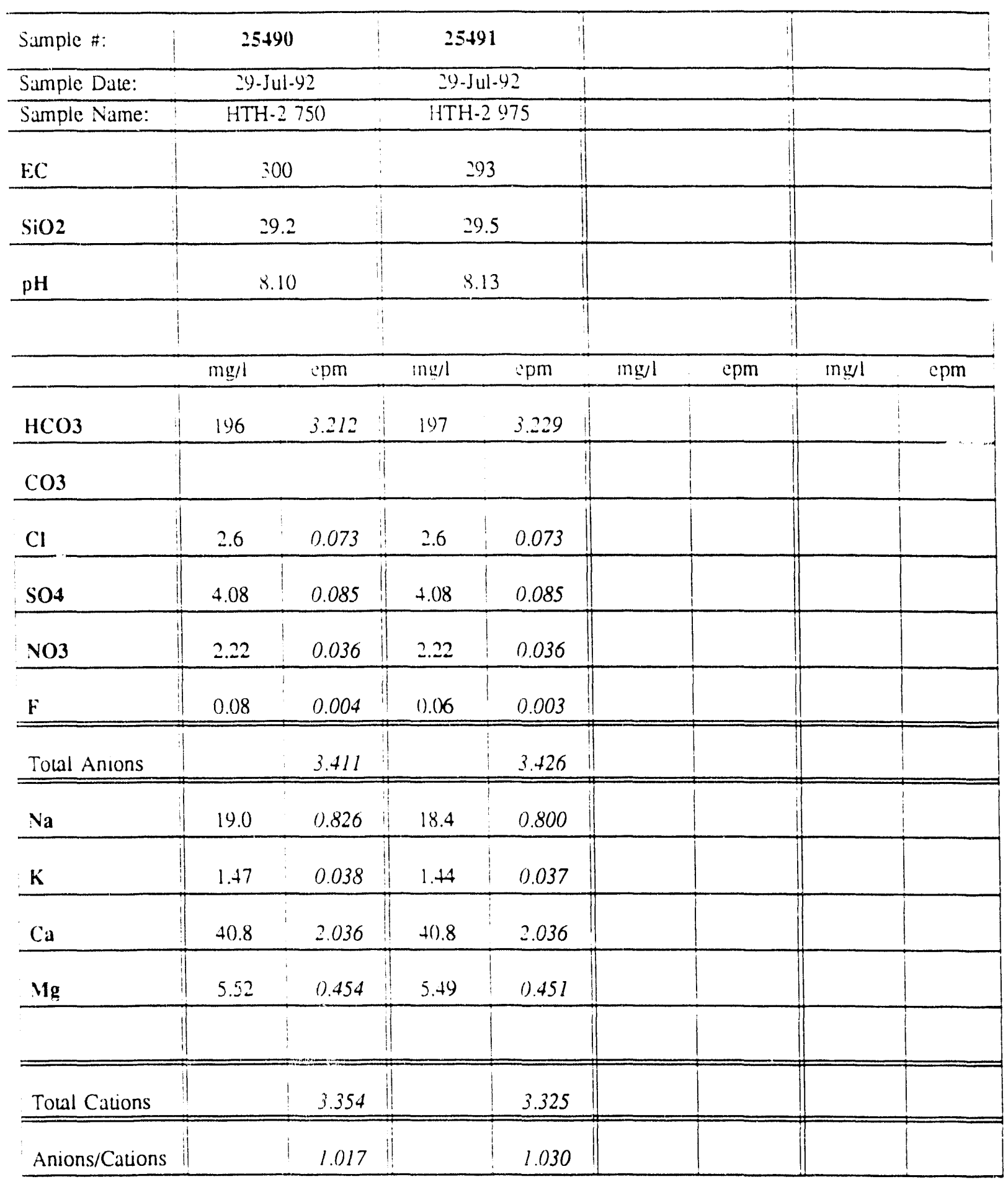




\section{WRC Waterlab}

Requested by: Chapman. Jenny

Project: DOE Shoal Offsite
Date submitted: 11-Aug-92

File name: 25558DOE.dat

\begin{tabular}{|c|c|c|c|c|c|c|c|c|}
\hline Sample \#: & \multicolumn{2}{|c|}{25558} & & & & & & \\
\hline Sample Date: & \multicolumn{2}{|c|}{ 6-Aug-92 } & & & & & & \\
\hline Sample Name: & \multicolumn{2}{|c|}{ HTH -2650} & & & & & & \\
\hline $\mathrm{EC}$ & \multicolumn{2}{|c|}{304} & & & & & & \\
\hline $\mathrm{SiO2}$ & \multicolumn{2}{|c|}{28.9} & & & & & & \\
\hline \multirow[t]{2}{*}{$\mathrm{pH}$} & \multicolumn{2}{|c|}{8.27} & & & & & & \\
\hline & $\mathrm{mg} / \mathrm{l}$ & $\mathrm{epm}$ & ing/l & epm & $\mathrm{mg} / \mathrm{l}$ & epm & $\mathrm{mg} / \mathrm{l}$ & epm \\
\hline $\mathrm{HCO} 3$ & 194 & 3.180 & & & & & & \\
\hline $\mathrm{CO} 3$ & & & & & & & & \\
\hline $\mathrm{Cl}$ & 2.7 & 0.076 & & & & & & \\
\hline SO4 & 4.11 & 0.086 & & & & & & \\
\hline $\mathrm{NO3}$ & 2.13 & 0.034 & & & & & & \\
\hline Total Anions & & 3.376 & & & & & & \\
\hline $\mathrm{Va}$ & 19.0 & 0.826 & & & & & & \\
\hline $\mathbf{K}$ & 1.47 & 0.038 & & & & & & \\
\hline $\mathrm{Ca}$ & 40.7 & 2.031 & & & & & & \\
\hline $.1 \mathrm{~g}$ & 5.48 & (1).451 & & & & & & \\
\hline & & & & & & & & \\
\hline Total Cations & & 3.346 & & & & & & \\
\hline Anions/Cations & & 10009 & & & & & & \\
\hline
\end{tabular}


DATE

FILMED

$2 / / 9 / 93$ 
